\title{
Das leis da natureza à ordem econômica: direito natural e fisiocracia
}

\author{
Thiago Vargas \\ Doutorando em Filosofia \\ Universidade de São Paulo [USP] | CAPES [PDSE]
}

From the Laws of Nature to the Economic Order: Natural Law and Physiocracy

\section{RESUMO}

A partir de um exame de textos escritos por Du Pont de Nemours, Le Mercier de la Rivière, Victor Riquetti de Mirabeau e François Quesnay, e tendo em vista a unidade da teoria política formada e desenvolvida pela fisiocracia, buscaremos examinar como a análise econômica dessa doutrina encontra suas condiçôes de emergência a partir de uma elaboração política que lhe é precedente: o jusnaturalismo. Assim, destacaremos a importância desse retorno filosófico para a compreensão de conceitos como produto líquido ou mesmo para a ênfase dada à agricultura. Essa abordagem nos permitirá melhor avaliarmos de que forma o estudo das riquezas não se emancipa de uma teoria social e política que viceja, no final das contas, no tradicional terreno do direito natural.

\section{PALAVRAS-CHAVE}

Fisiocracia; Direito natural;

Economia política; Science nouvelle;

Quesnay.

\begin{abstract}
By analyzing works written by Du Pont de Nemours, Le Mercier de la Rivière, Victor Riquetti de Mirabeau and François Quesnay, and in view of the unity of political theory shaped and developed by the physiocracy, this paper examines how the economic analysis of this doctrine only finds its condition of possibility based on a previous political ground, the natural law. Thus, we aim to emphasize the importance of this "philosophical comeback" to the understanding of concepts such as net product or even the emphasis given to agriculture. This approach will allow us to better assess how the study of wealth does not emancipate itself from a social and political theory that ultimately flourish in the traditional field of natural law.
\end{abstract}

\section{KEY WORDS}

Physiocracy; Natural Law; Political Economy; New Science; Quesnay. 


\section{Introdução}

Célebre pelo Quadro Econômico, a teoria fisiocrática estabelece seus fundamentos sobre dois eixos filosóficos. O primeiro, objeto de frequente atenção da fortuna crítica, é uma teoria do conhecimento, exposta no verbete Evidência (I756), publicado na Enciclopédia. O segundo insere a fisiocracia na esteira do jusnaturalismo, cujas noçóes são expostas sobretudo no artigo Direito Natural, escrito por François Quesnay. Privilegiaremos a análise deste segundo eixo, seguindo as leituras de textos como $A$ ordem natural e essencial das sociedades politicas, de Le Mercier de la Rivière, alguns escritos de Du Pont de Nemours, do marquês de Mirabeau, Nicolas Baudeau e Le Trosne e do Despotismo da China, do próprio Quesnay, pois entendemos que tais são as obras que melhor nos permitem compreender a questão. A partir de uma leitura atenta dos textos, buscaremos restituir o lugar da análise econômica no seio do pensamento político fisiocrático, destacando a importância desse "retorno filosófico" para a compreensão de conceitos centrais, como o produto líquido, ou mesmo para trazer à luz a ênfase dada à agricultura. Pretendemos assim ressaltar que ao privilegiarmos consideraçóes de cunho filosófico, sem necessariamente retomarmos a uma leitura dos aspectos analíticos da doutrina, poderemos melhor compreender em que medida a fisiocracia pôde, servindo-se de noçóes como ordem natural e leis naturais, arrogar-se o título de ciência nova.

\section{A natureza, a ordem e a lei: o êxito da agricultura}

Publicada em 1767 por Du Pont de Nemours, a coletânea de textos fisiocráticos intitulada Fisiocracia, ou Constituição natural do governo mais vantajoso ao gênero humano inclui o verbete Direito Natural, escrito por François Quesnay. Ocupando um lugar de proeminência, este artigo encabeça a sequência de escritos escolhidos: trata-se de um importante alicerce para a compreensão da doutrina fisiocrática. Afinal, a própria estrutura da coletânea, conforme nos revela Nemours, situa as questôes de direito natural e da ordem natural como pontos de partida para o fisiocracismo, ali apresentadas como conhecimentos prévios e necessários à plena compreensão dos escritos econômicos. Em um mapa da exposição geral da doutrina, o Quadro Econômico, tratando da ordem social física, e as Máximas gerais do governo econômico, tratando das leis naturais e da ordem mais vantajosa, seriam, respectivamente, o segundo e terceiro passo após a explicaçáo do que a fisiocracia entende por direito natural (Nemours, I768, p. XXI).

Recordemos ainda que no Discurso do editor, texto que precede a compilaçáo dos textos de Quesnay, Nemours ressalta a importância concedida pelos fisiocratas ao direito natural, conceito essencialmente ligado e subordinado à noção de ordem natural, entendimento por diversas vezes reafirmado por Quesnay e Mirabeau em ou- 
tras obras. Afinal, conforme lemos na Filosofia Rural, "cabe ao próprio Deus esclarecer os verdadeiros adoradores, basta-nos conduzir os homens pelo conhecimento e pela consideração de seu próprio interesse, a convergir ao bem universal, à ordem natural, princípio e base da ordem moral de nosso mundo, princípio e base do Direito natural e da Lei natural" (Mirabeau; Quesnay, I763, p. XLI). Ordem, direito e leis naturais: os leitores acostumados com textos do jusnaturalismo moderno náo tardarão a identificar o vocabulário aqui mobilizado.

Contudo, na fisiocracia o emprego desses termos requer, de antemão, algumas nuances. A fim de tornarmos as explicaçóes posteriores mais claras, e assumindo o risco de temporariamente simplificarmos algumas questóes que mereceráo um exame mais detido, digamos, em poucas palavras, que a ordem natural pode ser entendida como uma criaçáo divina imutável, assegurando a prosperidade de todas as sociedades e guiada por leis determinadas; seu conteúdo é também físico, ou seja, há uma dimensão propriamente material, o que compreende a própria natureza e a reprodução de todas as coisas. Quanto às leis naturais, são regras fixas que ao mesmo tempo compóem e derivam dessa ordem, e os indivíduos podem alcançá-las através de sua liberdade de inteligência para, enfim, obter tudo o que for necessário para prover sua subsistência. Se a ordem natural precede e contém o direito natural, isso não significa em nenhum momento a diminuição da preeminência de suas normas: as leis naturais serão elementos indispensáveis na filosofia da nova ciência, pois indicam os caminhos para assegurar aos homens - devidamente estimulados e guiados pela evidência - o gozo pleno de todas as vantagens concedidas pela ordem natural e física. Algumas preciosas linhas são esclarecedoras a respeito destes temas, trecho no qual Nemours inicia por definir a noção de ordem natural:

A ordem natural é a constituição física que o próprio Deus deu ao universo, e pela qual tudo se opera na Natureza. Neste sentido geral e vasto, a ordem natural em muito precede o direito natural do homem; estende-se para muito além do homem e do que o interessa, abrange a totalidade dos seres [...]. Ela prescreve-nos, soberanamente, as leis naturais às quais devemos nos conformar $\mathrm{e}$ submetermo-nos, sob pena de perder, em razão proporcional a nossos erros e nosso desvario, a faculdade de fazer o que nos é vantajoso e de sermos assim privados do uso de nosso direito natural (Nemours, 1768, p. X).

O estudo das leis da ordem natural e física não é algo que interessa os fisiocratas apenas a partir da década de I760, quando os escritos sobre economia se multiplicam e a fisiocracia se encontrará em seu auge. Desde a segunda edição de seu Ensaio físico sobre a economia animal, de 1747 , Quesnay definia a existência do direito natural e de leis que deveriam definir o justo e o injusto absoluto, e essa discussão é realizada precisamente em um capítulo dedicado à liberdade - assunto que, quase dez anos depois, encerraria o verbete Evidência. São ali estabelecidas duas espécies de direito: o natural e o legítimo. Os direitos naturais são definidos como aqueles que a natureza nos concedeu, tais como o de velar por nossa conservaçáo e, para isso, o direito de 
podermos adquirir a porção de bens necessária para nossa sobrevivência. A outra, o direito legítimo, é a ordem jurídico-legislativa estabelecida, que oferece um corpo positivo de leis. O objetivo da ordem positiva é, assim, refletir o corpo de leis do direito natural, já que as leis naturais nunca podem ser destruídas.

Quase vinte anos depois do Ensaio, o artigo Direito natural inicia-se com uma definição ampla e vaga, mas já claramente apontando a ligação da matéria tratada com o campo conceitual e semântico relativo ao conceito de propriedade: "o direito natural do homem pode ser definido vagamente como o direito que o homem tem às coisas próprias ao seu usufruto" (Quesnay, OC, I, Le Droit Naturel, Cap. II, p. III), ou, como se diz mais precisamente logo adiante, "ficaremos bem convencidos de que o direito natural de cada homem se reduz, na realidade, à porção que ele pode obter por seu trabalho" (ibid., p. II4).

$\mathrm{Na}$ fisiocracia, o modelo universalista da ordem e a conformação da administração do governo às prescriçôes naturais buscam realizar a defesa de um modelo baseado na propriedade fundiária e da observação do direito dos proprietários. Para efetivá-lo e defendê-lo contra afrontas, como Quesnay enfatiza na Terceira Observação da Análise aritmética do Quadro Econômico, além de observar que a segurança da propriedade se encontra inscrita na ordem natural, deve-se garantir que ela seja assegurada pela autoridade administrativa do governo.

Este ponto talvez seja mais bem ilustrado ao recorrermos à obra $A$ ordem natural e essencial das sociedades politicas, publicada em julho de 1767 por Le Mercier de la Rivière, tida como o desenvolvimento das ideias propostas no Despotismo da China (março de 1767), de Quesnay. No capítulo dois desse livro, lemos que o direito de propriedade decorre imediatamente e indissociavelmente do direito de auto-conservação, e que, juntos, eles constituem uma unidade denominada de duas formas: ou propriedade pessoal, que diz respeito ao direito de prover sua própria subsistência, ou a propriedade mobiliária, relativa aos objetos e frutos do trabalho realizado pelo indivíduo. Enfim, o ato de poder tornar-se proprietário é táo importante quanto o ato de perseverar na existência, pois "o direito de adquirir e o direito de conservar formam conjuntamente tão apenas um único e mesmo direito, mas considerado em tempos diferentes" (Rivière, I9Io, p. 9) e, recorrendo a um campo terminológico lockiano, como já o fizera Quesnay em outras oportunidades, arremata afirmando que o homem tem propriedade exclusiva de sua pessoa e das coisas que adquiriu por seu trabalho.

A propriedade é também a noção reguladora dos argumentos que buscam explicar a desigualdade de condiçôes. Identificando a fonte desta no estado de natureza e mesmo compreendendo-a como uma regra inscrita nas leis naturais, Rivière afirma que a desigualdade de condiçôes naturais é justa por essência, posição que acabará por legitimar a desigualdade de condiçôes civis. Não se trata somente de uma mera diferença corporal ou de forças, elementos já perceptíveis e sensíveis no estado de 
natureza, mas, sobretudo, de uma desigualdade fundada sobre o direito de propriedade e as condiçóes naturais de habilidade para obtê-la: se todos potencialmente podem ser proprietários exclusivos dos frutos de seu trabalho, e certamente são proprietários exclusivos de sua própria pessoa, segue-se que é necessário que alguns possuam mais do que outros, na medida em que, tendo em vista as diferenças de talentos e faculdades, certos indivíduos adquirem mais coisas do que seus semelhantes. Todo direito à propriedade é justo e deriva de uma ordem física determinante para os arranjos da ordem moral.

Além disso, toda ordem social e mesmo a história das instituiçóes remonta a uma origem comum da qual tudo deriva: o estabelecimento e proteção da propriedade fundiária. É ela que garante a cristalização da sociedade civil regrada por leis e sob a tutela e proteçáo dos magistrados, assegurando, assim, o cumprimento de determinações físicas e naturais. Desta forma, a sociedade deve ter sua estrutura e instituiçôes organizadas a partir da garantia da propriedade exclusiva dos bens e da pessoa: "a partilha das colheitas deve ser instituída de maneira que o estado do proprietário fundiário seja o melhor estado socialmente possível" (Rivière, I9IO, p. I7 [24]).

Em suma, a propriedade é apresentada como um direito natural e elemento essencial tanto para o fundamento da sociedade e a regulação das relaçóes entre indivíduos quanto para a geração de riqueza, ou, como lemos na Quarta Máxima das Máximas Gerais do Governo Econômico de um Reino Agrícola, "a segurança da propriedade é o fundamento essencial da ordem econômica da sociedade. Sem a certeza da propriedade o território permaneceria inculto" (Quesnay, OC, I, Maximes générales, IV, p. 567). Ainda segundo Quesnay, para que a propriedade seja garantida e a economia possa realizar suas funçóes, é necessário que haja governo — pois homens em estado natural não "poderiam obter riquezas pela agricultura ou pelo pastoreio de rebanhos, pois não haveria poder tutelar para garantir a sua propriedade" (id., OC, I, Le Droit Naturel, cap. IV, p. II9).

Nesse sentido, a confederaçáo social e o governo acabam por expandir o uso do próprio direito natural às coisas, ao possibilitar seu usufruto e assegurar garantias aos proprietários. Uma vez consolidadas em um corpo jurídico de normas, as leis positivas executadas pela administraçáo devem, por sua vez, o tanto quanto possível, ser deduçóes exatas das leis primitivas, tendo como objetivo principal o estabelecimento de uma sanção punitiva capaz de castigar os homens movidos por paixóes desregradas e que venham, assim, a infringir a lei. Se, por um lado, é necessário deixar que os interesses guiem a realização do trabalho agrícola, o governo deve, por outro, garantir o respeito ao direito de propriedade. Neste contexto é apresentada a definição de prosperidade, nos seguintes termos: "cultivar a terra com o maior sucesso possivel, e defender a sociedade contra os ladróes e os maldosos. A primeira parte é ordenada pelo interesse, a segunda é confiada ao governo civil” (id., OC, II, Despotisme de la Chine, p. IоI7). 
Portanto, qualquer corpo político que pretenda assegurar as melhores máximas de governo e garantir que se obterá da ordem física a maior vantagem possível deve velar pelo respeito das leis naturais. Estas, embora derivem de princípios de experiência, devem ser deduzidas racionalmente, e, nessa formada, dadas ao conhecimento dos governantes. É o que garante, afinal, o estabelecimento da justiça: "sem o conhecimento das leis naturais, que devem servir de base à legislação humana e de regras soberanas para a conduta dos homens, não há nenhuma evidência de justo $\mathrm{e}$ de injusto, de direito natural, de ordem física e moral" (id., OC, I, Le Droit Naturel, cap. V, p. I22), escreve Quesnay.

Os fisiocratas não deixam dúvidas de que se trata de uma ordem natural física e que esta condição determina as formas de organização social, moral ${ }^{1}$, econômica e de natureza dos governos. Mirabeau confirma que esta ordem de conteúdo físico precede, contém e informa as leis que regem a ordem social, também natural: "de que se trata o estudo da ordem natural física da qual depende absolutamente a ordem social? Em primeiro lugar, da evidência do funcionamento físico da natureza [...]" (Mirabeau, I775, p. 8I7). O modelo social vislumbrado pelos fisiocratas deriva, portanto, das leis estabelecidas num mundo físico a ser conhecido filosoficamente pelos homens.

\section{Leis físicas e despotismo legal}

Conforme escreve Du Pont de Nemours, "tudo prova a nós que existe essencialmente uma tal ordem, uma lei universal e física que foi estabelecida pelo criador do mundo, e segundo a qual os seres, as produçóes, as riquezas, tendem a se perpetuar e mesmo a se multiplicar o tanto quanto possível" (Nemours, 1766, p. 3). Ou seja, as leis da economia política e as condiçóes de reprodução da riqueza são determinadas pela dimensão material que compóe o universo fisiocrático. Dotar as leis naturais de um conteúdo físico é um procedimento que permitirá a Quesnay fornecer ao direito natural análises de caráter propriamente econômico, estipulando a sacralidade do trabalho da agricultura, a obtenção do produto líquido e a função do governo em relação ao bom uso da economia. Vejamos como isso se realiza.

Em Despotismo da China, Quesnay não hesita em esclarecer que o poder de legislar é originariamente pertencente ao "Todo-poderoso" e se exprime no conjunto formado pela "ordem natural fisica" (Quesnay, OC, II, Despotisme de la Chine,

\footnotetext{
1 Conforme lemos em nota de Quesnay a um texto de Mirabeau: "entre nós, para nós, tudo é físico, e a moral daí deriva”. Citado em Weulersse (I9ı0b, p. I22. Grifo nosso). Em relaçáo à célebre frase de Quesnay, Luiz Roberto Monzani afirma, entáo, que "no fundo [para Quesnay e os fisiocratas] todas as leis são físicas. $\mathrm{O}$ moral não é senáo um aspecto do físico (Monzani, 20I4, p. 3i).

2 O termo, de Marianne Fischman, parece-nos bastante apropriado para explicar algumas nuances que Quesnay opera em relação à doutrina do direito natural. Fischman explica como Quesnay entende a ciência do direito não somente como aquela que determina um conjunto de regras necessárias para estabelecer o bem comum, mas, antes, como o fisiocrata destaca o papel físico das leis naturais e de que maneira estas terminam por estabelecer uma ligação essencial entre a economia e a política. Cf. Fischman, 1998.
} 
p. IOI5). As "leis físicas", na explicação de Quesnay, são eventos físicos da ordem natural; se consideradas em relação à economia, configuram as determinaçóes materiais da produção, existindo independentemente vontade política ou humana. ${ }^{3}$ Assim, cabe ao soberano conhecer os preceitos destas leis perenes e imutáveis, desta ordem "mais vantajosa para o gênero humano" (ibid.), para assegurar abundância e prosperidade de bens para o reino. Ouçamos Quesnay:

As leis naturais da ordem das sociedades são as próprias leis físicas da reprodução perpétua dos bens necessário à subsistência, à conservação e à comodidade dos homens. Ora, o homem não é instituidor destas leis que fixam a ordem das operaçóes da natureza e do trabalho dos homens, que deve concorrer com aquele da natureza à reproduçáo dos bens dos quais eles têm necessidade. Todo este arranjo é de constituiçáo física, e esta constituiçáo forma a ordem física que submete os homens reunidos em sociedade a estas leis e que, por sua inteligência e sua associação, podem obter com abundância pela observação destas leis naturais, os bens que lhes são necessários (Quesnay, OC, II, Despotisme de la Chine, p. IOI5).

Para a maior efetividade desses princípios, é preciso uma administração, um governo econômico que garanta a aplicação das prescriçóes naturais-físicas. Estas questôes nos conduzem ao polêmico conceito de despotismo elaborado pelos fisiocratas.

No capítulo VIII do Despotismo da China, Quesnay explica em maiores detalhes as diferenças da autoridade tutelar ali defendida em relação às outras formas de governo - o despotismo arbitrário, a aristocracia, a monarquia e a democracia -, todas potencialmente contrárias à ordem natural física, submetidas aos interesses particulares nocivos e às paixôes desenfreadas, enfim, sob o jugo do arbitrio. Em suma, sustenta que nessas formas de governo os interesses particulares se sobreporiam ao interesse público, quer dizer, iriam de encontro às prescriçóes da ordem natural física. Ora, cabe à autoridade e aos legisladores observarem estas normas, a fim de garantir os maiores benefícios e felicidade à naçáo, pois, caso contrário, "a negligência do estudo destas leis fundamentais favorecem a introdução das formas de imposiçóes mais destrutivas e leis positivas mais contrárias à ordem econômica e política" (ibid., p. Ioı3). A autoridade deve ser única, mas essa centralização deve ser compreendida não em termos do arbítrio de um déspota, como queria Montesquieu, mas por uma determinação do governo a partir do constrangimento causado pelas próprias leis físicas: náo são os homens que convencionam como as regras de governo devem operar para a vantagem da sociedade, pois o funcionamento da autoridade — seus deveres, suas açôes, seus limites, seus poderes — só podem ser encontrados nas regras inscritas na própria ordem física.

\footnotetext{
3 Veremos adiante que o governo tem um papel importante na aplicação dessas leis. Marx destaca esse ponto, e adiciona que o grande mérito dos fisiocratas foi o de pensar as formas de produção como "formas fisiológicas da sociedade, que emergem da própria necessidade de produçáo [...]. São leis materiais [...]” (Marx, 1975, p. 353).
} 
A autoridade tutelar é soberana com o intuito de fazer cumprir as regras naturais que, se bem observadas, fornecem a melhor forma de governo possível, favorecendo a economia, o corpo social, a política, a moral. A própria ordem natural contém em si o arquétipo dos governos e os modelos normativos a serem seguido pelas leis positivas. ${ }^{4}$ Como ressalta Du Pont de Nemours, nem os homens nem os governos fazem a lei, "eles a declaram, conduzem-na ao seio da sociedade" (Nemours, 1966, p. 390), exortando na sequência que é preciso atentar para a verdade encerrada na utilização dos termos franceses législateur e législation - e não em légisfacteur ou légisfaction. Os indivíduos não fazem a lei: simplesmente a anunciam. Nesse mesmo sentido, o verbete Direito Natural reafirma a inevitabilidade em se chegar ao melhor governo possível através do conhecimento das "leis imutáveis", que asseguram não somente a liberdade e a propriedade, mas também as disposiçóes econômicas que possibilitam tirar melhor proveito da riqueza:

A razão esclarecida, conduzida, e levada ao ponto de conhecer com evidência
a marcha das leis naturais, torna-se a regra necessária do melhor governo
possível, onde a observaçáo destas leis soberanas multiplicariam abundante-
mente as riquezas necessárias à subsistência dos homens, e à manutenção da
autoridade tutelar, cuja proteçáo garante, aos homens reunidos em sociedade,
a propriedade de suas riquezas e a segurança de suas pessoas (Quesnay, OC, I,
Le Droit Naturel, cap. V, p. I23).

Com o exercício da razão e com a aplicação ao estudo da natureza, é possível conhecer as leis naturais e as regras que regem a ordem física. Portanto, cabe sobretudo aos governantes e aos legisladores trabalhar como verdadeiros jurisconsultos $d a$ lei natural, isso é, tendo como objetivo o conhecimento evidente e adequado das normas essenciais da natureza. Quesnay deixa claro que, para que um corpo político se aproxime da perfeição, não basta que apenas o governante se comprometa a este conhecimento, mas, antes, que os súditos também tenham acesso a esse saber, de forma a minimizar os dissensos no próprio ato de legislação.

Da compreensão da ordem natural derivam as regras responsáveis por formar, enfim, a base da ciência econômica. As leis de circulação, do produto líquido, da renda, das relaçóes entre proprietários e cultivadores, do papel da classe industrial e mesmo o lugar de incidência dos impostos, podem e devem ser compreendidas à luz das leis naturais e suas determinaçóes materiais. Desta forma, a política seria apenas uma técnica garantidora do bom funcionamento das normas sociais e econômicas fornecidas pelo conteúdo físico do mundo, uma aplicação das normas fundamentais já determinadas por uma ordem e pelas leis que a integram. Conforme Quesnay explica no artigo Direito Natural, os processos políticos e econômicos inscrevem-se nesta ordenação imutável, cabendo aos governos aplicá-los, garantindo o

${ }^{4} \mathrm{O}$ termo arquétipo é de Quesnay. Cf. verbete Le Droit Naturel, cap. V. 
cumprimento da ordem mais vantajosa possível: "a lei fundamental de todas as outras leis positivas [...] é a instituição da instrução pública e privada das leis da ordem natural, regra soberana de toda legislação humana e de todo comportamento civil, político, econômico e social" (ibid., p. I22).

A observaçáo das leis naturais garante a prosperidade da nação, e o próprio princípio da agricultura como fonte de riqueza encontra-se nas regras estabelecidas pelo direito natural. Assegurar o cumprimento do que a lei natural prescreve é, portanto, seguir uma determinação da ordem física que indica o cultivo da terra como fonte principal obtenção do excedente: "as próprias leis [naturais] asseguram o êxito da agricultura, e a agricultura é a fonte das riquezas que satisfazem as necessidades dos homens e constituem as forças necessárias ao seu sustento" (id., OC, II, Despotisme de la Chine, p. IO2I).

Portanto, a sociedade, cujo corpo legislativo deve reproduzir o conjunto de normas prescrito pela ordem natural, encontra suas bases tanto na garantia da propriedade e da segurança dos indivíduos quanto nos processos econômicos que asseguram a felicidade e a vantagem aos homens. As leis positivas ou legítimas devem, assim, garantir a reprodução das riquezas conforme estabelecido pela ordem natural física. ${ }^{5}$ Mas como explicar, entáo, o êxito continuado da economia e da agricultura?

\section{0 vinculum serum: as leis da economia}

Os conceitos de cultivo, de agricultura e de produto líquido têm papel fundamental na doutrina fisiocrática. Como explica Du Pont de Nemours em I764, o produto líquido é um excedente (ou sobra) que somente pode derivar da agricultura e do trabalho na terra, ou, como lemos nas adiçóes incluídas na segunda edição do Quadro econômico (1759), das atividades da mineraçáo e da pesca. Apenas a Natureza ou, como primeira causa, Deus - pode oferecer generosamente os dons (nas Máximas Gerais, Quesnay fala em “dádivas”) e frutos do solo: este excedente será propriamente aquilo que permite erigir o fundamento econômico fisiocrático. Afinal, "a terra é a única fonte de riquezas, e é a agricultura que as multiplica" (Quesnay, OC, I, Maximes générales, III, p. 567), sendo que todo o restante responsável por indicar e garantir uma competente ordem econômica e uma boa administração aumento da população, ampliação do comércio e indústria, garantia do bom preço, comércio internacional — sáo corolários desta máxima. Somente o solo pode gerar excedente e, consequentemente, franquear o rendimento; assim sendo, a classe que trabalha na terra é a única que pode ser adequadamente denominada de produtiva. Náo hesitemos em citar uma elucidativa passagem de Nemours a este respeito:

\footnotetext{
5 Nas palavras de Quesnay, "o fundamento da sociedade é a subsistência dos homens e as riquezas necessárias à força que deve defendê-los; assim, somente a ignorância poderia, por exemplo, favorecer a introduçâo das leis positivas contrárias à ordem da reproduçáo e da distribuição regular e anual das riquezas do território de um reino" (Quesnay, OC, I, p. I22).
} 
Como a agricultura é o único trabalho ao qual o Céu concorre sem cessar e que seja uma criação perpétua, enquanto o comércio e a indústria são somente uma manutenção e uma transformação das coisas já criadas, os produtos da agricultura que pelo comércio adquirem um valor venal são os únicos que fornecem um benefício líquido e real; isto é, que possa enriquecer um homem sem empobrecer outro. A partir do momento que o valor da colheita reembolsou as despesas que a fizeram nascer, e que são necessárias para perpetuá-la, a sobra é o que constitui o produto líquido sobre o qual somente se pode determinar um rendimento. Esta sobra nada custa a ninguém, pois todos aqueles que se ocuparam dela foram pagos; absolutamente, devemos ela ao solo, à Providência, à benevolência do Criador, à chuva que Ele faz cair e que transforma em ouro. Esta sobra, base de todas os rendimentos, é o grande laço, o vinculum serum da Sociedade (Nemours, I9II, p. 5 [9], nota I).

As palavras de Nemours encontram-se em pleno acordo com passagens de obras como a Filosofia Rural, de Mirabeau (mas com cruciais contribuiçóes de Quesnay), que atribui de forma clara um papel especial à agricultura, por ser a única atividade na qual o homem atua com a colaboraçáo direta de um associado muito especial: Deus, produzindo os frutos através de sua indústria e fornecendo, assim, seu trabalho aos homens. O trabalho na terra é, afinal, o labor mais próximo possível da atividade divina. A própria agricultura é definida como "manufatura de instituição divina, na qual o fabricante tem por associado o Autor da natureza, o próprio Produtor de todos os bens e todas as riquezas" (Mirabeau; Quesnay, I763, p. 98).

Mas, como esse trabalhador invisível poderia fornecer aos homens uma produção excepcional, a única que gera excedente? A concepção de produção fisiocrática só pode ser plenamente compreendida em sentido físico, ou seja, como uma regeneração ou renascimento, como capacidade gerar e recriar matérias primas para a subsistência, dentro dos limites impostos pelo conteúdo físico do mundo. Apenas o setor agrícola e os trabalhos relacionados diretamente à natureza poderiam ser produtivos, enquanto as outras classes em nada contribuiriam para a produção em si (já que um artesão-marceneiro, por exemplo, não teria a capacidade de produzir ou gerar a árvore e a madeira, mas somente a de trabalhar sobre esta matéria prima, alterando-a e dando a ela novas formas). A natureza do objeto ao qual o trabalho se aplica — se ele é capaz de regeneração e de um primeiro movimento —, e não sua utilidade, portanto, é o critério que permite distinguir os setores produtivos dos estéreis. Com isto, podemos retirar do rótulo estéril uma parte de sua carga de negatividade ou do sentido aparentemente pejorativo que carrega consigo, uma vez que os comerciantes e os artesãos podem ser extremamente úteis para a sociedade e desempenhar importante papel na circulação das riquezas, embora, ao apenas modificar a forma das matérias primas, não trabalhem sobre produtos dotados de capacidade de regeneraçáo, realizando apenas um consumo. 
Podemos aqui evocar algumas passagens esclarecedoras da Filosofia Rural a respeito desta questão. Recordemos que Mirabeau, após explicar a formação da sociedade através do trabalho de uma família ${ }^{6}$ que se divide em três classes — a primeira representada pelos pais que garantem a ordem e a segurança; a segunda, produtiva, cuja representação é uma parte da prole responsável pelos trabalhos agrícolas; e a terceira, os filhos encarregados da conservaçáo e preparaçáo dos produtos, inicialmente chamados de "industriais" —, destaca a importância da segunda classe de acordo com o critério de produção: na ordem econômica, o primeiro movimento que impulsiona a circulaçâa e o trabalho das outras classes vem propriamente da terra, única "fonte da produção", capaz de incessantemente regenerar-se. A partir disto, a terceira classe pode ser chamada por seu verdadeiro nome: estéril, pois apenas transforma a matéria prima e "embora se diga que ela produz a forma, produzir a forma é nada produzir, no verdadeiro sentido que damos aqui a esta palavra, e na realidade da coisa". Já o trabalhador produtivo deve realizar um trabalho de regeneração junto à terra, operar com a matéria viva e em inicial movimento, para, finalmente, poder novamente realizar sua colheita no ano seguinte. Desta forma, pelo cultivo agrícola é gerado um rendimento, definido como "o excedente do produto da terra para além daquilo que deve ser consumido em custo de exploraçáo para ocasionar a colheita seguinte". O caminho do rendimento, derivado do trabalho produtivo realizado pelos agricultores e circulando pela sociedade, é comparado ao sangue que percorre o corpo. Poderíamos dizer que há tanto uma função regenerativa operada pelo corpo econômico quanto um curso definido em suas operaçóes. E, de fato, mais adiante Mirabeau retoma estes temas para realizar uma leitura dos funcionamentos e da estrutura da ordem econômica sob o ponto de vista da circulaçáo, descrevendo a composição e disposição dos elementos do corpo, mas, para além disso, a própria descrição das regras de funcionamento de cada um dos órgáos que o compóe. Esse caminho serve para explicar o fluxo entre produção e despesas, já que estes obedecem, afinal, regras de circulação como todas as outras:

É no emprego e na regeneraçáo, isto é, na consumação perpétua e na reproduçáo, que consiste o movimento que condensa a sociedade, e que perpetua sua duração. É por isto que as despesas dão vida à reprodução, e que a produção repara as despesas. Esta circulação tem, como todas as outras, regras exatas de fluxo e de refluxo, que igualmente impedem e esgotam os canais, e suas obstruçóes (Mirabeau \& Quesnay, I763, p. IOI). ${ }^{7}$

\footnotetext{
6 E, mais adiante, o Estado é definido como "uma multidão de famílias ligadas pelas mesmas leis políticas, que tem um ponto comum de reuniáo, de obediência ao direito público" (Mirabeau \& Quesnay, I763, p. 9).

7 As citaçōes do parágrafo anterior são encontradas, respectivamente, nas páginas 6, 7, I3-14, isto é, ao longo da parte inicial do primeiro capítulo da obra.
} 
Essa é apenas uma das muitas passagens que mostram como a fabricação das noçóes fisiocráticas é alimentada por modelos ou paradigmas distintos (ora mecânico, ora fisiológico, ora anatômico), capazes, entretanto, de transitar entre si para melhor explicar o funcionamento e interação entre os objetos analisados. Este trabalho de formação de conceitos que explicam a realidade deve, como argumenta Quesnay, proceder diretamente do conhecimento das leis físicas e ser realizado a partir da conformação da linguagem àquilo que a ordem natural prescreve. Em outras palavras, poderíamos afirmar que conhecer e aplicar as determinaçóes da ordem é uma tarefa semiótica - e os fisiocratas seriam, por excelência, os semiólogos da ordem natural e física, os enunciadores da ciência econômica. Em uma passagem do segundo diálogo do texto Sobre o trabalho dos artesáos, lemos que os objetos na natureza não podem "desarranjar" a ordem física na qual se encontram inscritos, e que suas relaçóes, entre si e com o todo, podem ser estabelecidas segundo "ideias abstratas”. Desta forma, Quesnay dispóe de um instrumento conceitual pelo qual pode relacionar o trabalho dos indivíduos a grupos gerais denominados classe. Visitemos essas preciosas linhas:

A ideia de produção, ou de regeneração, que forma aqui a base da distinção entre as classes gerais dos cidadãos, é confinada dentro de limites físicos, tão rigorosamente reduzida à realidade que não mais se conforma às vagas expressōes utilizadas na língua ordinária. Mas não cabe a ordem natural se conformar a uma linguagem que somente exprime ideias confusas e equívocas; cabe às expressóes se conformar ao conhecimento exato da ordem natural, nas distinçôes rigorosamente submetidas à realidade (Quesnay, OC, I, Sur les travaux des artisans, p. 974).

O uso da linguagem, portanto, ou se quisermos ser mais específicos, dos signos, deve servir às expressóes da ordem natural, cujo acesso é explicado por meio de uma teoria do conhecimento fundada na noção de evidência. Só assim, portanto, poderão adquirir plenamente seu significado. Esse é o caso, por exemplo, do conceito de produçâo, que se refere necessariamente a um quadro conceitual capaz de dotá-lo de sua acepção precisa. Ao analisarmos o Quadro Econômico, veremos que somente a classe produtiva é capaz de obter o produto líquido, pois, na ordem da economia, somente esta categoria participa de um processo de regeneraçáo da matéria prima (ou, utilizando um termo que Quesnay insiste em utilizar, renascimento). Como a própria definição de classe produtiva nos indica, o labor na terra é o ponto de gravidade em torno do qual orbitam todos os trabalhos e todas as despesas. Isso explica como uma ideia é gerada e como passa a ser utilizada como ferramenta conceitual para descrever e se relacionar a outras etapas do processo econômico.

O consumo, por seu lado, é o exato contrário da produção, uma vez que se trata nada menos do que a "aniquilação de uma riqueza" (id., OC, II, Réponse au mémoire de M. H., p. 838). Quando um membro da classe estéril vende seu artigo ou produto, não há produção, mas somente despesa ou consumo. Isto ocorre porque um artesão, 
por exemplo, vende a matéria-prima que compóe o objeto e também seu labor: para Quesnay, o valor do trabalho é calculado como os custos e o dispêndio necessário para a subsistência e manutenção do indivíduo e de sua família. Em outras palavras, ao nos referirmos à classe estéril devemos ter em vista que "aí só há consumo e absolutamente nada de produção" (ibid., p. 837). Náo estaríamos distantes da ideia de Quesnay se denominássemos o trabalho produtivo como labor vivo e o consumo como labor morto.

O verbete Homens é notavelmente elucidativo quanto a esse ponto: após ter afirmado que somente um "Estado agricultor" é rico por ter produçóes anuais e bom preço, e ao argumentar que o salário ganho com o trabalho realizado é gasto para a subsistência do trabalhador e sua família, não gerando, portanto, nenhum tipo de riqueza ou excedente de produçáo, Quesnay afirma:

O fabricante que faz estofos, o costureiro que faz roupas, o sapateiro que faz sapatos, também não produzem riquezas tanto quanto o cozinheiro que faz o jantar de seu senhor, que um operário que corta madeira, que músicos que executam um concerto; eles são todos pagos sobre o mesmo fundo, e na razão dos ganhos atribuídos aos seus trabalhos, que eles gastam para sua subsistência; assim, eles consomem tanto quanto produzem: o produto de seu trabalho é, entâo, igual ao custo que seu trabalho exige; disto não resulta nenhum excedente de riquezas (Quesnay, OC, I, Hommes, p. 295).

A partir das considerações até aqui realizadas, podemos finalmente nos indagar: se todo trabalho é consumo e apenas a fertilidade da terra é suficiente para a geração do excedente, qual é propriamente o papel das diferentes modalidades e técnicas de trabalho agrícola?

Sem negar a exclusividade da produtividade da terra, a partir de uma reflexão sobre a eficiência e a utilização da técnica os fisiocratas sustentam que as formas de cultivo e o emprego de instrumentos para realizá-lo desempenham um papel fundamental para a obtenção do excedente. No verbete Arrendatários, escrito para o sexto volume da Enciclopédia, Quesnay sustenta que a grande cultura ou cultura em escala, conduzida por arrendatários ricos que pagariam seus adiantamentos aos proprietários de terra, consistiria no empreendimento mais vantajoso para a sociedade. Diferente da pequena cultura, na qual os meeiros dependem do proprietário para realizar seus serviços e trabalham geralmente em condiçóes técnicas menos produtivas - como o caso do uso de bois para a cultura —, os arrendatários possuem riqueza própria, utilizam melhores instrumentos para o cultivo (a força dos cavalos), garantem o maior benefício do produto líquido e do rendimento, e empregam, ainda, mão de obra camponesa para a colheita, melhorando, a vida da comunidade em todos os aspectos. Além disso, a riqueza levada ao campo através do empreendimento do arrendatário rico, realizador de grande cultivo, gera trabalho e aumento de bem-estar, ocasionando o crescimento da populaçáo do campo e maior interesse pela cultura do solo. Adicione-se a essas vantagens um importante elemento: ao agir 
sempre em busca de seu interesse próprio, o arrendatário contribui de forma eficaz a atender o interesse de todos, o bem geral, e proporciona vantagens e riquezas ao Estado e à sociedade.

Evidentemente, o arrendatário não é caracterizado somente como um interessado capaz de investir no campo seus recursos financeiros: trata-se, antes, de um empreendedor, figura de inteligência, talento e liberdade suficientes para bem realizar suas atividades, e que dispóe dos melhores meios técnicos possíveis para fazê-las. O produto líquido retirado da terra, portanto, depende, para sua maior vantagem, de uma teoria da produtividade, do desenvolvimento das formas de trabalho e do emprego da técnica; e, simultaneamente, esta posiçáo se harmoniza plenamente com as reflexôes sobre a ordem física, as divisóes das classes e a preponderância absoluta da fertilidade exclusiva da terra. Nas palavras de Quesnay, "as riquezas dos arrendatários fertilizam as terras, que multiplicam os animais, que atraem, que fixam os habitantes dos campos, e que fazem a força e a prosperidade da nação” (Quesnay, OC, I, Fermiers, p. I56).

Sem deixar de ser uma ciência das riquezas, a fisiocracia engloba um projeto político e social. Nas palavras de Catherine Larrère, a ciência que Quesnay pretende fundar "inclui o Estado [...]. A globalidade do projeto fisiocrático o coloca em continuidade com as teorias contemporâneas do governo e da sociedade" (1992, p. 194). $\mathrm{Na}$ economia interna do pensamento fisiocrático, o estudo das riquezas não se emancipa de uma teoria social e política cujos frutos, por sua vez, alimentam-se na tradição do direito natural e vicejam a partir do solo do pensamento filosófico.

\section{Referências bibliográficas}

\section{QUESNAY, F}

As citaçóes de Quesnay foram consultadas nas Euvres économiques complètes et autres textes (abreviadas de OC, seguida do número do tomo), editadas por Christine Théré, Loïc Charles e Jean-Claude Perrot, publicadas em dois tomos pelo INED, Paris, em sua edição de 2005. Foram citados os seguintes textos:

Essai physique sur l'œeconomie animale (segunda edição, 1747)

Fermiers (1756)

Évidence (1756)

Hommes (1757 [1908])

Le Droit Naturel (1765)

Analyse de la formule arithmétique du Tableau Économique (I766)

Sur les travaux des artisans (1766)

Réponse au mémoire de M. H. (I766)

Maximes Générales (1767)

Despotisme de la Chine (1767) 
BANZHAF, H. S. (2000) "Productive nature and the net product: Quesnay's economies animal and political". In: History of political economy, vol. 32, n. 3, pp. 517-55I.

BAudeau, N. (1767). “Avertissement”. In: Éphémérides du citoyen, ou Chronique de l'esprit national.

CARTELIER, J. (2004). "Economic theory as political philosophy: the example of the French Enlightenment”. In: BARENS, I., CASPARI, V. \& Schefold, B. (Eds.), Political events and economic ideas. Massachusetts: Edward Elgar, pp. 206-225.

Charles, L. \& STEINER, P. (1999). "Entre Montesquieu et Rousseau: la physiocratie parmi les origines intellectuelles de la Révolution Française". In: Études JeanJacques Rousseau, Rousseau: économie politique. Montmorency: Musée Jean-Jacques Rousseau, pp. 83-I59.

CiTTON, Y. (2004). "L'école physiocratique au coeur ou dans les marges des Lumières ?”. In: MASSEAU, D. (Dir.), Les Marges des Lumières. Genève: Droz, pp. 99-II2.

CitTON, Y. (1999). "Rousseau et les physiocrates : la justice entre produit net et pitié”. In: Études Jean-Jacques Rousseau, Rousseau: économie politique. Montmorency: Musée Jean-Jacques Rousseau, pp. I6I-I8I.

DumOnt, L. (1985). Homo Aequalis. Genèse et épanouissement de l'idéologie économique. Paris: Gallimard.

EysSidieUX-VAISSERMANN, A. (200I). "Rousseau et la science de l'économie politique dans l'Encyclopédie”. In: Ordre et production des savoirs dans l'Encyclopédie de Diderot et d'Alembert. Kairos, n. I8, pp. 47-74.

FisCHMAN, M. (1998). "Le concept quesnayen d'ordre naturel". In: Cahiers d'économie politique, n. 32. Paris: L'Harmattan, pp. 66-96.

FOUCAUlT, M. (1996). Les mots et les choses. Une archéologie des sciences humaines. Paris: Gallimard.

KUNTZ, R. (1982). Capitalismo e natureza. Um ensaio sobre os fundadores da economia política. São Paulo: Brasiliense.

LARRÈRE, C. (I992). L'invention de l'économie au XVIIt siècle. Du droit naturel à la physiocratie. Paris: PUF.

LARRÈre, C. (I992b). "Droit naturel et physiocratie”, In : Droit et économie, Archives de Philosophie du Droit, t. 37, p. 69-88.

Le Trosne, G-F. (I767). "De l'utilité des discussions économiques”, In: Physiocratie, ou constitution naturelle du gouvernement le plus avantageux au genre humain. T. IV. Cf. Discussions et développements sur quelques-unes des notions de l'économie politique.

Markovits, F. (1986). L'ordre des échanges. Philosophie de l'économie et économie du discours au XVIII siècle en France. Paris: PUF.

MARX, K. (1975). “Theories of surplus value”. In: Marx \& Engels, Collected Works, I86I-I863, vol. 30. New York: International Publishers. 
MEEK, R. L. (1962). The economics of physiocracy. London: George Allen and Unwin.

Mirabeau, V. R. de (176I). L'ami des hommes, ou Traité de la population. Avignon.

MiraBEAU, V. R. de (I775). Lettres sur la législation ou l'ordre légal, dépravé, rétabli et perpétué.

Mirabeau, V. R. de \& Quesnay, F. (I763). Philosophie rurale, ou économie générale et politique de l'agriculture, 3 tomos, Librairies Associés.

MONZANI, L. R. (20I4). "Raízes filosóficas da noção de ordem nos fisiocratas", In: Discurso, n. 44, pp. 9-54.

Nemours, Du P. de (I768). “Discours de l'éditeur”. In: Physiocratie. Paris.

Nemours, Du P. de (I766) "Tableau économique", In: Journal de l'agriculture, du commerce et des finances, T. v, Troisième Partie, Paris: Juin.

Nemours, Du P. de (1764). De l'exportation et de l'importation des grains.

Nemours, Du P. de (1966). Maximes du Docteur Quesnay. E. Daire (Ed.), Osnabrück: O. Zeller.

RIVIÈRE, Le M. de la (I9I0). L'ordre naturel et essentiel des sociétés politiques. Collection des économistes et des réformateurs sociaux de la France. Paris: Paul Geuthner.

Salvat, C. (2006). "Les articles 'CElÉconomie' et leurs désignants”, In: Recherches sur Diderot et sur l'Encyclopédie, pp. I07-I26.

SCHUMPETER, J. (2006). A history of economic analysis. Routledge, Taylor \& Francis e-Library.

Spector, C. (2006). Montesquieu et l'émergence de l'économie politique. Paris: Honoré Champion.

SpeCtor, C. (2017). Rousseau et la critique de l'économie politique. Bordeaux: Presses Universitaires de Bordeaux.

STEINER, P. (1998). La 'Science nouvelle' de l'économie politique. Paris: PUF.

VIDONNE, P. (1982). Essai sur la formation de la pensée économique. Nature, rente, travail. Grenoble: PV.

WeUleRsSe, G. (I9IOb) (Ed.). Les manuscrits économiques de François Quesnay et du Marquis de Mirabeau aux archives nationales, inventaire, extraits et notes. Paris: Paul Geuthner.

WeUlersSe, G. (I9IO). Le mouvement physiocratique en France (de I756 à 1770). Paris: Félix Alcan. 